\title{
MAHASANTRI SATISFACTION TOWARDS THE UNIVERSITY BOARDING SCHOOL: A SERVICE QUALITY APPROACH IN ISLAMIC HIGHER EDUCATION
}

\author{
R. Nadia R.P. Dalimunthe ${ }^{1}$, Dahlya Indra Nurwanti ${ }^{1}$, Siti Nuraeni Muhtar ${ }^{1}$, Nurul \\ Hilaliyah $^{2}$ \\ ${ }^{1}$ UIN Sunan Gunung Djati, Bandung \\ ${ }^{2}$ Institut Manajemen Koperasi Indonesia (IKOPIN) \\ siti.nuraeni@uinsgd.ac.id
}

Received: 19/12/2018, Accepted: 23/01/2019, Published: 28/01/2019

\begin{abstract}
Mahasantri (an Islamic university students) is an agent for Islamic Higher Education Institution to face the Moderate Islam Malay Era. In Indonesia, for example, there is a university boarding school program for Mahasantri to improve their personality and competence. This study is trying to find out whether the program has been aligned with their satisfaction. One of service they received in the boarding is English Language Learning program. They are going to be interviewed about their satisfaction toward the program. Then, the interview result will be analyzed to generate the satisfaction indicator referring to five dimensions of Service Quality (SQ) by Parasuraman and Berry (1991).
\end{abstract}

Keywords: students' satisfaction, university boarding school, service quality approach, Islamic higher education

\section{ABSTRAK}

Mahasantri (mahasiswa Islam) adalah agen Lembaga Pendidikan Tinggi Islam untuk menghadapi Era Melayu Islam Moderat. Di Indonesia, misalnya, ada program asrama sekolah untuk Mahasantri untuk meningkatkan kepribadian dan kompetensi mereka. Penelitian ini mencoba untuk mengetahui apakah program telah selaras dengan kepuasan mereka. Salah satu layanan yang mereka terima di asrama adalah program Pembelajaran Bahasa Inggris. Mereka akan diwawancarai tentang kepuasan mereka terhadap program ini. Kemudian, hasil wawancara akan dianalisis untuk menghasilkan indikator kepuasan mengacu pada lima dimensi Kualitas Layanan (SQ) oleh Parasuraman dan Berry (1991). 


\section{INTRODUCTION}

Customer satisfaction is a measure of how an organization's total product performs in relation to set of customer's expectations. (Hill, Nigel, Alexander, Jim, 1996, p: 18). Customer satisfaction depends on on the product's perceived performance relative to a buyer's expectations. If the product's performance falls short of expectations, the customer is dissatisfied. If performance matches expectations, The customer is satisfied. If performance exceeds expectations, The customer is highly satisfied and delighted. (Amstrong/Kotler, 2005, p:17). Most of the educational service program which make a giant mistake face a lot of difficulties because they don't pay enough attention to their customer satisfaction. Customer in education field, especially in higher education context, is the students. Students are the customers that should be considered not only their performances but also their satisfaction. The best competitive advantage against competitors is to keep customer satisfied.

In today's increasingly competitive environment, service oriented establishments are under the pressure of demonstrating that their services are customer-focused and that continuous performance improvement is being done. The higher education sector is not exempted from this reality. Students nowadays have many options available to them because of the existence of so many higher education institutions. In Islamic higher education alone, there are a lot of effort to deal with their students satisfaction. To gain competitive edge over the other institutions, it is a challenge for HEl's to look for marketing strategies that aim at improving quality, student satisfaction and student retention. As a result, competition to woo as many students as possible may become more and more intense. To make the matter harder, as a private institution, it does not have the "privilege" to receive any subsidies or financial assistance from the government (Teo, 2001).

In order to survive in this highly competitive market, Islamic higher education make a program to give an extra service for students. This program was called the university boarding school. This program provided many service including dorm, self-building, and learning program. One of learning program proposed is English Learning Program. However, since the first release of this program, there is no satisfaction test conducted. Therefore, this study is trying to find 
out students' satisfaction toward this program in order to improve the quality service of the Islamic Higher Education. Quality and satisfaction have long been recognized to play a crucial role. Considerable studies have been done on these two concepts. According to the study done by Alridge and Rowley (2001) an expectation that cannot be fulfilled on the institution is the key factor for students' withdrawal. This would lead to the premise that satisfaction with services may make the difference (Parasuraman, et.al. 1996). This study aims to examine the aspects of service quality and the level of satisfaction among the students of one of Islamic University in Bandung.

\section{LITERATURE REVIEW}

\section{University Boarding School Program}

Traditionally, Effendi (2008) defines Pesantren or Islamic boarding school as a place where santri (student) live and study Islamic knowledge. Pesantren as a unique education institution has several important elements which further differentiate it from common education institutions. Another definition of Islamic boarding school is that of Dhofier (1994) in Fatmawati (2017) who states that it is a traditional Islamic educational institution to study, understand, live and practice the teachings of Islam by emphasizing the importance of religious morality as a guideline of everyday behavior. According to Latif (2016), there are at least three reasons features defining pesantren; they are santri (the students), kiai (the religious leaders), and pondok (the dormitory). Santri live in pondok, and are regarded as having the same social background without allowing privilege to any particular santri. It is based on the principal of equality. All santri are under one rule which they must obey. Furthermore, the existence of pondok enables pesantren to integrate all santri's activities, both academic and social, in order to prepare santri with the knowledge and skills which will be beneficial once they return to their own society. At last, the kiai is the central figure of the pesantren. They are considered as the ones with a wide range of Islamic knowledge. It is in line with the main character of the Islamic Boarding School according to Fatmawati (2015) which is: (1) established as a part and the support of its own community; (2) in the implementation of education to apply equality and simplicity of the students (santri); and (3) to accomplish the mission of 'eliminating ignorance', especially tafaqquh fi al-din and spread the teachings of islam. In other words, 
Pesantren is a designed place where santri live for a period of time to learn the teachings of Islam and live the Islamic ways.

As an Islamic higher education institution, UIN Sunan Gunung Djati bandung also provides the students with facilities to learn the religion aside from the university majors. Pesantren or in this case is university boarding school program is an integral part of the university's Islamic culture. This higher education model is known as "Ma'had "Aly" or integrative Islamic Boarding School and Islamic Boarding School. Ma'had 'Aly (Bagian Proyek Peningkatan Ma'had Aly, 2004) is a higher education held more or less like boarding school with various cultures and traditions that surround it. Its similarity with the other Islamic Boarding School is the special facilities, such as dormitories, classrooms, libraries. However, it is also completed with means of actualization such as publications or lectures outside the boarding school. The establishment and management of Ma'had 'Aly as a Islamic Boarding School model's higher education program involves at least four factors (Bagian Proyek Peningkatan Ma'had Aly, 2004), namely: (1) the Quality of input quality, effective with a strong background of islamic boarding school and intellectuality and high morality; (2) the factor of teaching and learning system, in which the interaction between the mahasantri (university Islamic students) and teachers are conditioned in the atmosphere of partnership; (3) the quality factor of the teachers who master the classical Islamic book and Islamic teachings; and (4) the factors of equipment and facilities needed in teaching and learning process that supports, among others, adequate regulations and effectiveness of guidance and counseling.

Ma'had 'Aly's Curriculum is a curriculum consisting of national curriculum as the national standard compiled by each organization. The curriculum of a Ma'had 'Aly reflects the academic programs and professional programs and the competency standards to achieve by the graduates. The design of Ma'had 'Aly curriculum is structured by combining the scientific tradition of Islamic Boarding School with public university system. In general, the structure of Ma'had 'Aly curriculum is structured as follows; Basic Courses, Concentrated Courses, Skill Courses and Scientific Writing (Syukur: 2007 in Fatmawati: 2015). It could be inferred from the theories that the curriculum covers both Islamic 
teachings and general courses, including English.

\section{Student Satisfaction}

In the literature of services, the focus is on perceived quality, which results from the comparison of customer service expectations with their perceptions of actual performance (Zeithaml et.al., 1990, p. 23). Every stakeholder in higher education (e.g. students, government, professional bodies) has its own view of quality due to particular needs. This paper is concerned with one particular stakeholder in higher education: students. Perceived quality in this case deals with advisory services, curriculum, teaching quality, financial assistance and tuition costs, and facilities (Farahmandian et.al, 2013), and they have significant impact on student satisfaction. Rad \& Yarmohammadian (2006) defined student satisfaction as the willful accomplishment which results in one's contentment. The satisfaction plays a major role in deciding the originality and accuracy of a system especially the educational system as the higher the level of satisfaction, the higher will be the level of students' grooming their skill development, course knowledge and mentality (Malik, 2010). It is in line with Alridge and Rowley
(2001) who argue that when students perceive the institution's quality and standardized learning environment facilitated with intellectual faculty and appropriate facilities of learning and infrastructure, their interest in their organization will explicitly be retained. Meanwhile, Spooreen, et.al. (2007) posited a view that the organizational harmony, teachers' intellectual ability, professional development, transparency in students' evaluation, feedback and training are the important features that mentally develop the students. In the case of student satisfaction of university boarding school program, the perceived quality may also deal with the specific facilities of the boarding house as well as the program's organization.

Students' satisfaction is a multidimensional process which is influenced by various factors. MarzoNavarro, et.al. (2005), Appleton-Knapp \& Krentler (2006) identify two groups of influences on student satisfaction in higher education as personal and institutional factors. Personal factors cover age, gender, employment, preferred learning style, student's GPA and institutional factors cover quality of instructions, promptness of the instructor's feedback, clarity of expectation, teaching style. Wilkins \& Balakrishnan (2013) identified quality 
of lecturers, quality of physical facilities and effective use of technology as key determinant factors of student satisfaction. As well as, student satisfaction in universities is greatly influenced by quality of class room, quality of feedback, lecturer-student relationship, interaction with fellow students, course content, available learning equipment, library facilities and learning materials (Garcl a-Aracil, 2009; Kuh, et.al., 2001; Sojkin, et al, 2012). In addition to that, teaching ability, flexible curriculum, university status and prestige, independence, caring of faculty, student growth and development, student centeredness, campus climate, institutional effectiveness and social conditions have been identified as major determinants of student satisfaction in higher education (Douglas, et.al., 2006; Palacio, et.al., 2002). Various models and frameworks have been used by researchers to investigate the matter of student satisfaction. The one used in this research is SERVQUAL (Parasuraman, et.al., 1985) SERVQUAL is a most popular widely used service quality model which has been applying to measure students' satisfaction around the world. SERVQUAL is a questionnaire that has been designed, developed and tested in business environment, by Parasuraman in 1985 to measure service quality and customer satisfaction of a business taking five dimensions into consideration as tangibility, reliability, empathy, responsiveness and assurance (Weerasinghe, et.al., 2017).

\section{Classroom Management in ELT}

The focus of this paper is the student satisfaction on the classroom management of English program held in the university boarding school program. It specifically deals with the tutors, teaching methods, and teaching materials. Evertson and Weinstein (2006) refer classroom management to the steps teachers do to design a supportive learning environment for the students' academic and social emotional learning. There are five types of actions explained here to attain a high quality classroom management. Teachers must (1) develop caring, supportive relationships with and among students; (2) organize and implement instruction in ways that optimize students' access to learning. Additionally, Evertson and Weinstein (2006) state that teachers should; (3) encourage students' engagement in academic tasks, which can be done by using group 
management methods. Teachers also must; (4) promote the development of students' social skills and selfregulation. Marzano et al. (2003) refer to this as making students responsible for their behavior. Finally, Evertson and Weinstein (2006) state that teachers should be able to; (5) use appropriate interventions to assist students with behavior problems. In brief, classroom management is an ongoing interaction between teachers and their students. Brophy (2006) presents a similar definition: "Classroom management refers to actions taken to create and maintain a learning environment conducive to successful instruction (arranging the physical environment, establishing rules and procedures, maintaining students' attention to lessons and engagement in activities)." Both definitions emphasize the importance of actions taken by the teacher to facilitate learning among the students.

Speaking of classroom management in the field of English Language teaching (ELT), there are at least two principles to consider by the teachers; they are meaningful learning and learner-centeredness. Michael (2004) defines meaningful learning as learning with understanding. When students have reached the level of meaningful learning, they would be able to perform tasks and activities using the information and knowledge they have. In meaningful learning, learners are conditioned to integrate the new knowledge to the existing relevant one. It is in line with Harmer (2008) who believes that one of the key elements to successful English learning is engagement. When a learner is engaged with the material in a learning activity, they can learn better and more effectively. Harmer (2008) also points out that under the influence of humanistic and communicative theories, learner-centeredness in which learner's needs and experiences are the main focus of the learning process has been emphasized. It is believed that the success of language learning lies in the students' exposure to the language. Learners should be given tasks to work on and in the process of performing these tasks, real learning is taking place. In other words, an ELT classroom management requires the teachers to be organizer as well as facilitator to make sure that the learning process is meaningful and learner's autonomy is carried out. This way, the learning is considered to be effectively conducted.Isi tinjauan pustaka adalah uraian/landasan teori-teori ilmiah yang berkaitan dengan pokok bahsan 
kajian/penelitian, ditulis fonta Times New Roman 12. Seluruh sumber teori yang dikutip dalam bab ini harus ada di dalam daftar rujukan/pustaka.

\section{METODE}

To understand the students' satisfaction, this study occupied the SERVQUAL measurement. SERVQUAL measures the difference between what is expected from a service encounter and the perception of the actual service encounter (Parasuraman, Zeithaml, \& Berry, 1988). A modified SERVQUAL questionnaire comprising 21 items was used as a survey instrument in this study. The 21 items are classified into three factors: classroom management, learning support, and loyalty. Classroom management involves ten statements which are derived from Brophy's conceptualization of classroom management (in Evertson \& Weinstein, 2013), including physical space and resources, creating and maintaining rules, routines and procedures, methods of maintaining and engaging students attention, disciplinary interventions, and student socialisation actions. Students' learning support was measured based on the aspect of student life (Gruber, Fuß, Voss, \& Gläser-Zikuda, 2013; Letcher \& Neves, 2010; Tessema, Ready, \& Yu, 2012). Loyalty, or in this research referring to students'

Retention (Carvalho \& Mota, 2010; Gallifa \& Batallé, 2013; Schee, 2010), is explored from the students' sense of comfort, the desire to stay in the dormitory, and their willingness to recommend the dormitory school. The survey was administered electronically on the internet over the 20 students, who are randomly selected from the whole population of 200 students. The selected students determined their agreement with the 21 questionnaire statements in five-point Likert scales.

\section{RESULT AND DISCUSSION}

The students were generally satisfied with classroom management, especially teachers' physical performance (100\% strongly agree), promised material $(90 \%$ strongly agree), and hospitality (90\% strongly agree). The students' satisfaction with the other aspects of classroom management is illustrated in the following table: 
Table 1: Students' Satisfaction with Classroom Management

\begin{tabular}{|c|c|c|c|c|c|c|}
\hline No. & Items & $\begin{array}{c}\text { Strongly } \\
\text { Agree }\end{array}$ & Agree & Fair & Disagree & $\begin{array}{l}\text { Strongly } \\
\text { Disagree }\end{array}$ \\
\hline 1 & $\begin{array}{l}\text { Teachers' physical } \\
\text { performance }\end{array}$ & 20 & & & & \\
\hline 2 & $\begin{array}{l}\text { Teachers' promised } \\
\text { materials }\end{array}$ & 18 & 2 & & & \\
\hline 3 & $\begin{array}{l}\text { Teachers' } \\
\text { hospitality }\end{array}$ & 18 & 2 & & & \\
\hline 4 & $\begin{array}{l}\text { Teachers' teaching } \\
\text { ability }\end{array}$ & & & 3 & 17 & \\
\hline 5 & $\begin{array}{l}\text { Students' } \\
\text { engagement in } \\
\text { classroom activities }\end{array}$ & 15 & 2 & 1 & & \\
\hline 6 & $\begin{array}{l}\text { Clear teaching and } \\
\text { learning objectives }\end{array}$ & & 4 & 12 & 4 & \\
\hline 7 & $\begin{array}{l}\text { Teachers' sufficient } \\
\text { feedback }\end{array}$ & & 3 & 15 & 2 & \\
\hline 8 & $\begin{array}{l}\text { Clear assessment } \\
\text { criteria }\end{array}$ & & 1 & 16 & 3 & \\
\hline 9 & $\begin{array}{l}\text { Teachers' } \\
\text { availability for } \\
\text { discussion }\end{array}$ & & 12 & 6 & 2 & \\
\hline 10 & $\begin{array}{l}\text { Constructive } \\
\text { homework }\end{array}$ & & 14 & 2 & 2 & \\
\hline
\end{tabular}

This shows that the students have a high level of service with regards to the teachers' personality. However, that students are not significantly satisfied with the teachers' teaching ability and the conformation of learning objectives, feedback and assessment.

Regarding the learning supports, the students show some quite high dissatisfaction. From the five learning supports (classroom environment, internet access, library, refectory, and computer lab), three reach $30 \%$ of dissatisfaction and above. They are classroom environment (14), internet access (13) and computer lab (15). 
Table 2: Students' Satisfaction with Learning Support

\begin{tabular}{|c|l|c|c|c|c|c|}
\hline No. & \multicolumn{1}{|c|}{ Items } & $\begin{array}{c}\text { Strongly } \\
\text { Agree }\end{array}$ & Agree & Fair & Disagree & $\begin{array}{c}\text { Strongly } \\
\text { Disagree }\end{array}$ \\
\hline 1 & $\begin{array}{l}\text { Classroom } \\
\text { environment }\end{array}$ & & & 6 & 14 & \\
\hline 2 & Internet Access & & & 5 & 13 & 2 \\
\hline 3 & Library & & 2 & 10 & 6 & \\
\hline 4 & Refectory & & 15 & 5 & & \\
\hline 5 & Computer Lab & & & 4 & 15 & 1 \\
\hline
\end{tabular}

The interesting satisfaction trend appears from the factor of loyalty. The students show high loyalty to the campus. It reaches $80 \%$ of the students, which is equal to 16 students, recommending the school to their colleagues. Even though they show some dissatisfactions with the learning facilities and the weak classroom structure, their loyalty keeps high.

Table 3: Students' Loyalty

\begin{tabular}{|c|l|c|c|c|c|c|}
\hline No. & \multicolumn{1}{|c|}{ Items } & $\begin{array}{c}\text { Strongly } \\
\text { Agree }\end{array}$ & Agree & Fair & Disagree & $\begin{array}{c}\text { Strongly } \\
\text { Disagree }\end{array}$ \\
\hline 1 & Students' comfort & 3 & 15 & 2 & & \\
\hline 2 & Students' long stay & 2 & 18 & & & \\
\hline 3 & $\begin{array}{l}\text { Students' } \\
\text { willingness to } \\
\text { recommend the } \\
\text { dormitory campus }\end{array}$ & 2 & 16 & 2 & & \\
\hline
\end{tabular}

\section{CONCLUSION}

Islamic University Boarding School has conducted a good effort to improve their service quality. Regarding the English Learning Management given during teaching and learning process in this program showed a good respond on students' satisfaction. The students were generally satisfied with classroom management, especially teachers' physical performance $(100 \%$ strongly agree), promised material $(90 \%$ strongly agree), and hospitality (90\% strongly agree). However, this is just a surface research that need to investigate more in order to improve the quality of Islamic Higher Education service. 


\section{REFERENCES}

Alridge, S. \& Rowley, J. (2001). Conducting a Withdrawal Survey. Quality in Higher Education, 7(1), 55-63.

Appleton-Knapp, S. \& Krentler, K. (2006). Measuring student expectations and their effects on satisfaction: the importance of managing student expectations. Journal of Marketing Education, pp. 254-264.

Bagian Proyek Peningkatan Ma'had 'Aly, Pedoman Penyelenggaraan Ma'had 'Aly, Direktorat

Brophy, J. (2006). History of Research on Classroom Management. In C. M. Evertson \& C. S. Weinstein (Eds.), Handbook of classroom management. Research, practice, and contemporary issues (pp.1743). Malwah, NJ: Lawrence Erlbaum Associates.

Carvalho, S. W., \& Mota, M. de O. (2010). The role of trust in creating value and student loyalty in relational exchanges between higher education institutions and their students. Journal of Marketing for Higher Education. https://doi.org/10.1080/088412410 03788201.

Douglas, J., Douglas, A. \& Barnes, B. (2006). Measuring student satisfaction at a UK university. Quality Assurance in Education, pp. 251-267.

Effendi, J., (2008). A Renewal without Breaking Tradition: The Emergence of A New Discourse in Indonesia Nahdhatul Ulama during the Abdurrahman Wahid Era. Yogyakarta: Interfidei.

Evertson, C. M. \& Weinstein, C. S. (Eds.) (2006). Handbook of classroom management. Research, practice, and contemporary issues. Mahwah, NJ: Larence Erlbaum Associates, Inc.

Evertson, C. M., \& Weinstein, C. S. (2013). In Handbook of Classroom Management: Research, Practice, and Contemporary Issues. Routledge.

Fatmawati, Erma. (2015). Integration of Islamic Boarding School and University: Typology Study and Curriculum of University Student Islamic Boarding School. International Journal of management and Administrative Sciences (IJMAS), Vol. 5, No, 10, 01-17.

Garcl a-Aracil, A. (2009). European graduates' level of satisfaction with higher education. Journal of Higher Education, 57(1), pp. 1-21

Gallifa, J., \& Batallé, P. (2013). Student perceptions of service quality in a multi-campus higher education system in Spain. Quality Assurance in Education. https://doi.org/10.1108/096848810 11035367

Gruber, T., Fuß, S., Voss, R., \& GläserZikuda, M. (2013). Examining student satisfaction with higher education services. International Journal of Public Sector Management. https://doi.org/ 10.1108/09513551011022474

Harmer, J. (2007). The Practice of English Language Teaching. Essex: Longman.

Kuh, G. \& Hu, S. (2001). The effects of student-faculty interaction in the 1990s. Review of Higher Education, 24(3), pp. 309-332.

Latif, Muhaemin.

(2016). MULTICULTURAL EDUCATION IN ISLAMIC BOARDING SCHOOL (A Descriptive Study of Pesantren DDI Mangkoso, South Sulawesi). JICSA, Vol. 05-No. 02, 231-250. 
Letcher, D. W., \& Neves, J. S. (2010). Determinants of undergraduate business student satisfaction. Research in Higher Education Journal, 6(1).

Malik, E M. (2010). The Impact of Service Quality on Students' Satisfaction in Higher Education Institutes of Punjab. Journal of Management Research, Vol. 2 No. 2, 1-11.

Marzano, R. J., Marzano, J. S., \& Pickering, D. J. (2003). Classroom management that works. Research-based strategies for every teacher. Alexandria, VA: Association for Supervision and Curriculum Development (ASCD).

Marzo-Navarro, M., Iglesias, M. \& Torres, M. (2005). A new management element for universities: satisfaction with the offered courses. International Journal of Educational Management, 19(6), pp. 505-526.

Michael, J.A. (2004). Mental Models and Meaningful Learning. JVME, 31 (1).

Palacio, A., Meneses, G. \& Perez, P. (2002). The configurationof the university image and its relationship with the satisfaction of students. Journal of Educational Administration, 40(5), pp. 486-505.

Parasuraman, A., Berry, L. \& Zeithaml, V. (1985). A conceptual model of service quality and its implications for future research. Journal of Marketing, pp. 41-50.

Parasuraman, A., Zeithaml, V. A., \& Berry, L. L. (1988). Servqual: A multiple-item scale for measuring consumer perc. Journal of Retailing, 64(1), 12.

Pendidikan Keagamaan dan Pondok Islamic Boarding School Direktorat
Jendral Kelembagaan Agama Islam Departemen Agama RI 2004.

Rad, A. M. M. \& Yarmohammadian, M. H. (2006). A study of relationship between managers' leadership style and employees' job satisfaction. Leadership in Health Services, 19(2), 11-28.

Sojkin, B., Bartkowiak, P. \& Skuza, A. (2012). Determinants of higher education choices and student satisfaction: the case of Poland. Higher Education, 63 (5), pp. 565-81.

Spooren, P., Mortelmans, D. \& Denekens, J. (2007). Student evaluation of teaching quality in higher education: development of an instrument based on 10 Likertscales. Assessment and Evaluation in Higher Education, 32, 667-679.

Schee, B. A. V. (2010). Students as Consumers: Programming for Brand Loyalty. Services Marketing Quarterly, 32(1), 32-43. https://doi.org/10.1080/15332969.2 011.534331.

Tessema, M. T., Ready, K., \& Yu, W. (2012). Factors affecting college students' satisfaction with major curriculum: Evidence from nine years of data. International Journal of Humanities and Social Science, 2(2).

Wilkins, S. \& Balakrishnan, M. S. (2013). Assessing student satisfaction in transnational higher education. International Journal of Educational Management. pp. 146-153.

Zeithaml, V. A., Parasuraman, A. and Berry, L. L. (1990). Delivering Quality Service: Balancing Customer Perceptions and Expectations, The Free Press, New York, NY. 